\title{
Agents of dissent: African student organizations in the German Democratic Republic
}

\author{
Sara Pugach
}

\section{Introduction}

Tens of thousands of exchange students passed through the German Democratic Republic (GDR) during its forty years of existence. Among them were Africans from colonies and newly independent nations across the continent. When they arrived, many joined Nationale Hochschulgruppen (NHG), organizations that represented students from specific countries. For the Sozialistische Einheits Partei (SED), which governed the GDR through single-party rule, and its youth wing the Freie Deutsche Jugend (FDJ), the main function of the NHG was to organize annual Independence Day festivities for the nations they represented. ${ }^{1}$ NHG celebrations typically involved speeches on the evils of imperialism along with 'traditional' dances or other performances. They were well attended, with invitees including members of the club throwing the party, other exchange students, SED members and FDJ representatives. The national clubs were complemented by an overarching organization representing all Africans in the GDR, whether or not they were students: the Union der Afrikanischen Studenten und Arbeiter in der DDR (Union of African Students and Workers in the GDR, or UASA). The UASA was theoretically where Africans could turn for assistance in all manner of situations, including affairs related to housing, acculturation in the GDR, and interactions with East German universities.

When the authorities did think of the NHG in political terms, they saw them either as rubber stamps for GDR viewpoints or as forums in which to inculcate Marxism-Leninism. The former belief was reflected in the Independence Day speeches held at NHG celebrations, which addressed issues such as the ongoing struggle against the racist Ian Smith regime in Rhodesia. ${ }^{2}$ The FDJ was likewise hopeful that mentors assigned to the different African student associations would help promote discussion and acceptance of socialism.

Quickly, though, the NHG took on a function that was both alarming and distasteful to the SED and FDJ: the NHG provided sites of dissent, often at discrete moments when crises emerged in specific African nations, or during general power struggles. African students were emboldened to speak - or even to gather together to protest - in these instances. The organizations offered a space for protest within

\footnotetext{
Sara Pugach is Professor of History at California State University, Los Angeles, and author of Africa in Translation: a history of colonial linguistics in Germany and beyond, 1814-1945 (University of Michigan Press, 2012), in addition to various journal articles and book chapters. She is currently writing a book on the history of African students in the German Democratic Republic from 1949 to 1975. Email: spugach@exchange.calstatela.edu

${ }^{1}$ University of Leipzig Archives (UAL), FDJ 894, 'Rektor, KMU, Richtlinien zur Würdigung von Feiertagen ausländischer Studierender', undated but after 1973.

${ }^{2}$ UAL, ZM 3965, 'Mali 1975-1985, plans for the "Tag der Malinesischen”, 1977.
} 
a tightly policed socialist nation, where both citizens and visitors were subject to surveillance by the infamous Ministerium für Staatssicherheit - the Stasi. Protests also certainly took place on an individual level, as they did for the Angolan students Marcia Schenck addresses in this issue, and the ability to use one's position as an invited guest to subvert authority was immensely powerful (Schenck 2019). What the NHG did was allow select groups of students - usually, if not always, conationals - to come together and amplify their respective voices.

Africans sometimes had more opportunity to make grievances public than East Germans, for whom the threat of punishment was much greater. This was, simply, because the GDR needed the African students. West Germany - the Federal Republic (FRG) - had instituted a policy called the Hallstein Doctrine in 1955, which held that it would not conduct diplomatic relations with nations that recognized the GDR. As former colonies throughout Africa gained independence, many wanted to remain non-aligned in order to receive aid from both Soviet and American blocs. Not wanting to alienate the FRG or lose out on its aid, which was more substantial than that of the GDR, these nations did not establish formal ties with East Germany in the 1950s or 1960s. Rather, the GDR set up less powerful trade missions. Student exchanges were therefore one of the other means that the SED used to forge alliances. The potential for retribution against protesters was dependent more on the judgement of the African state whose students were in the GDR than on the GDR itself.

The students therefore became a tool used to negotiate with nations such as Ghana, Guinea and Mali, the three countries closest to the Soviet bloc and the GDR in the early 1960s. The SED hoped that, by funding exchanges and contributing in other ways, for example with development projects, they might convince African leaders to launch formal diplomatic relations. While this did not happen until the Hallstein Doctrine was retracted in 1970, there was a strong incentive to keep African students in the GDR despite their political activity.

There were many occasions for African students to express their displeasure with political developments at home. In early 1962, Guinean students in the GDR joined with Guineans across Europe to protest against President Sékou Touré's crackdown on striking teachers. Around the same time, there were early signs of discontent among students from eastern Nigeria, those who would eventually support the breakaway region of Biafra during its war with the federal government from 1967 to 1970 . The officially sanctioned Nigerian NHG ultimately fractured, creating an expressly Biafran Club that the SED scrambled to dismantle. Meanwhile, the Kenyan Student Club also divided along political and ethnic lines, with a new group emerging to challenge the FDJ-sponsored organization.

The SED attempted to suppress protests that conflicted with their own policies. Quinn Slobodian has addressed international student protest in the FRG, arguing that foreign students galvanized their West German classmates into political action around events such as the assassination of Congolese leader Patrice Lumumba. In the FRG, such protests took on a sense of opposition not only to unjust colonial and postcolonial regimes, but to the West German state. Students saw the state as imperialist, and reacted against perceived West German collaboration with the US and its other allies to smash non-Western political aspirations (Slobodian 2012).

The GDR, however, positioned itself as an anti-imperialist, anti-racist champion. Along with the USSR, the GDR declared solidarity with people fighting 
colonialism. To the extent that students in the GDR were faithful Marxists - and evidence suggests that not many of them were - they would have found it difficult to agitate against the GDR on some of the issues that motivated students in the FRG, including the death of Lumumba and apartheid in South Africa (Slobodian 2012). On the surface, GDR positions on both were in line with those of the anti-imperial community. The GDR not only denounced Lumumba's assassination, it also established a close relationship to his widow, Pauline, with SED secretary Walter Ulbricht writing her a letter of sympathy that was also a promise of political support after her husband's death. ${ }^{3}$ She made a state visit to the GDR in $1965,{ }^{4}$ and worked with the GDR on securing places for Congolese students in East German universities. ${ }^{5}$ The GDR condemned apartheid as an institution and rebuked the FRG for its continued support of the South African government (Winrow 1990: 66). The GDR also provided refuge for dissidents from the African National Congress (ANC).

Yet as Slobodian has shown, African students also complained about the political hypocrisy of the GDR, and questioned its anti-imperial credentials. The UASA's second congress, in 1961, featured tensions over a possible resolution against Egyptian President Gamal Abdel Nasser's suppression of progressives, and at the third congress in 1962 over the repatriation of Cameroonian workers to their native country despite the considerable peril they might face from a hostile regime (Slobodian 2013).

The relationship between the GDR and certain African regimes became, in this respect, a growing subject of contention. The increasingly authoritarian nature of some African governments produced sharp divisions among the students, as well as conflict with the SED. Student dissent undermined the GDR's fragile efforts to curry favour with these African governments, or ran contrary to the political positions of the Soviet bloc. The protests thus provide a window onto how student opposition functioned in the GDR. This opposition was not as open as that of foreign students in the FRG, where they marched in the streets, had hunger strikes and held sit-ins (Slobodian 2012). On rare occasions, students in the East did make their displeasure public; for example, in 1970 and 1971, thirty to forty Malian students occupied Mali's trade mission in East Berlin to condemn the increasingly repressive nature of the Moussa Traore regime. ${ }^{6}$ However, protest in the GDR usually meant writing joint letters, holding meetings not approved by the SED, or disrupting the gatherings that it did sanction. In this manner, African students took it upon themselves to turn their national clubs from organizers of annual Independence Day celebrations into loci of dissent and debate.

\footnotetext{
3‘Walter Ulbricht an Pauline Lumumba', Neues Deutschland, 16 February 1961.

4'Pauline Lumumba beendet Aufenthalt in unserer Republik', Neues Deutschland, 20 March 1965 .

${ }^{5}$ Ministerium für Auswärtige Angelegenheiten der DDR (Ministry of Foreign Affairs of the GDR/MfAA), B290.79, 'Studium von Kongolesischen Studenten in der DDR und Bewerbungen, 1963-1972', Schmid, Third Secretary in Cairo, to the MfAA, 28 August 1966, concerning Pauline Lumumba.

${ }^{6}$ MfAA, C718.74, 'Beziehungen zwischen der DDR und Mali auf dem Gebiet des Hoch- und Fachschulwesens, 1967-71. Hinweise für ein Gespräch des Genossen Dr. Kiesewetters mit dem Leiter der Kulturabteilung des MfAA Malis', 7 June 1971.
} 


\section{The first African student organizations in the GDR}

The first umbrella organization for African students in East Germany was established in 1958. It was called the Vereinigten Afrikanischen Studenten in der DDR (VAS), and had members from Madagascar, Kenya, Ghana, Sierra Leone, the Gambia, Senegal and Guinea. ${ }^{7}$ With the exception of Ghana, all of these countries were still under colonial control. ${ }^{8}$ Even at this early stage, there was conflict. The GDR's Nigerian students already had their own, exclusively Nigerian group, and tried to stall the foundation of the VAS. According to the VAS leader, a student from the Gambia, the Nigerians were unhappy with the idea of a student organization that linked all African students in the GDR together, regardless of nationality. ${ }^{9}$ While the Gambian student did not say so explicitly in his letter to the Nigerian group, he implied that the Nigerians resisted the organization because it would be arranged around Pan-African principles that asserted African unity against imperial oppression. ${ }^{10}$

The Pan-African nature of the VAS was evident in its constitution. It was conceived as a forum where African students could meet and discuss Africa-related topics. The organization would awaken the 'spirit of unity, helpfulness, and cooperation among its members', so that they might 'provide their best service to mother Africa'. The group would fight for the independence of all Africa and function as the 'mirror of Africa' in the GDR. Its activities would not be restricted to the GDR, since it would forge bonds with other 'democratic' African organizations in Africa and beyond. ${ }^{11}$

Why the Nigerians wanted to stop an umbrella organization from developing is unclear. Nigerians were the first African students to come to the GDR, in 1951, and remained the largest contingent in 1958; perhaps they felt that, given their own numbers, they did not need broader representation. The Nigerians may also have aligned their politics with those of the East German state. As Slobodian has shown, the SED was wary of Pan-Africanism and its emphasis on African as opposed to national unity (Slobodian 2013: 652-5). ${ }^{12}$ This explained the SED's reluctance to accept the umbrella organization that formed after the VAS, the Union der Afrikanischen Studenten und Arbeiter in der DDR (UASA). The SED believed that UASA, formed in 1960, was too independent, and apt to make statements that contradicted official party lines. Even after

\footnotetext{
${ }^{7}$ Stiftung Archiv der Parteien und Massenorganisationen der DDR im Bundesarchiv (SAPMO), DY/24/6822, 'Zentralrat der FDJ, Zentralarchiv, Bestand: Intern. Verbindungen, 1958-1962; L. I. Jarju, Kulturleiter der Vereinigten Afrikanischen Studenten in der DDR an dem Sekretär der Gruppe der Nigeria Studenten in der DDR', 26 May 1958.

${ }^{8}$ Guinea decolonized later that year, in October.

${ }^{9}$ 'L. I. Jarju, Kulturleiter der Vereinigten Afrikanischen Studenten in der DDR an dem Sekretär der Gruppe der Nigeria Studenten in der DDR'.

${ }^{10}$ Ibid.

${ }^{11}$ SAPMO, DY/24/6822, 'Zentralrat der FDJ, Zentralarchiv, Bestand: Intern. Verbindungen, 1958-1962; Sekretär der Gruppe der Nigeria Studenten in der DDR an Herr M.', 28 May 1958.

${ }^{12}$ There was also a certain wariness that Pan-Africanism might supersede Marxism-Leninism as the foremost ideology among African students. See SAPMO, DY/24/6707, 'Intern. Verbindungen (FDJ) 1962-1963; Stellv. Schulleiter, Jugendhochschule Wilhelm Pieck, Intern. Lehrgänge an Werner Lamberz, Sekretär des ZR der FDJ', 19 February 1962.
} 
East German authorities placed the UASA under the control of the Deutsche Afrikanische Gesellschaft (DAfriG), it resisted state pressure.

Both the VAS and the UASA had to contend with individual national groups. Just as the Nigerians had rejected the VAS, the groups from Ghana and Kenya originally rebuffed the UASA. ${ }^{13}$ From the beginning, the groups representing individual African states existed alongside the umbrella African organization. Their memberships were exclusive to students from specific countries. As of 1959, there were at least two loose national groups for sub-Saharan African students: one for Nigerians, and another for students from Madagascar. There were twenty-three national student groups in all, encompassing students from any country with more than two individuals attending university in the GDR. The division of student affairs of the GDR's Department for Higher Education and the leadership of the FDJ were both responsible for overseeing the groups and their activities. ${ }^{14}$ FDJ representatives were the most involved, since they acted as mentors to the international students, working to ensure that their guests understood and approved of Marxism-Leninism, and that they behaved appropriately during their stay in the GDR. ${ }^{15}$

Fissures inside the national groups existed from the start. For example, by 1960 a Sudanese group had formed, but it was a group in name only. The FDJ forced its cohesion from above. The Sudanese students were not politically unified, and their leadership was weak. Some students were in favour of Sudan's military regime, while others belonged to the country's communist party. One of the students was a staunch supporter of Egypt's Nasser. The members of the group did not discuss their political differences, and their head believed that each student's education was a personal affair, not a political matter. ${ }^{16}$

Given the early difficulties that both the umbrella student organizations and the individual national groups encountered, it is perhaps not surprising that many became involved in protest. Political activity either unified students behind a specific cause, or divided them along ethnic or sectarian lines. Whatever the case, the FDJ and other GDR authorities found it difficult to control student activism, and even when they did, tensions within the groups and between the groups and the East German state remained.

\section{Resisting recall: Guinean reaction to forced repatriation}

In late 1961, only three years after Guinean independence, the Guinean teachers' union produced a pamphlet criticizing the government's lack of support for their profession. The teachers, many of whom had studied in Europe and had close bonds with communists in France, denounced the Touré government for being insufficiently communist, or not communist at all. The union went on strike, and five of its top leaders were arrested and imprisoned (Tatum 2002: 86).

\footnotetext{
${ }^{13}$ UAL, Pror. Stu. A 17, 'Einschätzung einzelner Landsmannschaften', 3 May 1960.

${ }^{14}$ UAL, Pror. Stu. A 17, 'Report betr. Ausländische Studierende', 20 January 1959.

${ }^{15}$ UAL, Pror. Stu. A 17 , 'Niederschrift über die erste Beratung mit den Betreuern der Auslandsstudenten', 12 February 1959.

${ }^{16}$ 'Einschätzung einzelner Landsmannschaften'.
} 
While the Soviets and their satellites, including the GDR, had considered Toure a staunch communist ally, the strike would prove otherwise. Touré expelled the Soviet ambassador from Guinea for his supposed involvement in organizing the strike. Among the Guineans in Europe, however, was a core of ardent Marxists who were disappointed that Touré had not ushered in the revolution. Thus Guinean students in the GDR, coordinating with their counterparts in Paris, Moscow and Prague, organized to protest against Touré.

It might have seemed as though the GDR, a Soviet ally, would have backed the students, since they were proving more faithful to Marxism-Leninism than their president. Yet the situation in Guinea was shifting quickly, and the GDR's Ministry of Foreign Affairs and university officials found it difficult to absorb all the new information coming from their trade mission in Guinea. They did not want to offend Touré, one of the African leaders who seemed most open to the East. Authorities also had difficulty containing growing student agitation. There had already been some anxiety among the Guinean contingent before the strike; in 1960, six Guineans in the GDR were recalled to Guinea. Upon hearing the news that he was to return, one of the students fled to West Berlin, frightened of what might happen if he went home. The Touré government had also asked the GDR to keep a close watch on its students, and to provide reports on their activities.

Touré's crackdown on the teachers' union provided sufficient motivation for Guinean students throughout Europe to press for change. Without GDR knowledge, forty-two Guineans in Leipzig and Jena sent a telegram to the Touré government, demanding the release of political prisoners. They gathered without GDR permission in Leipzig on New Year's Day 1962 and held a series of secret meetings both before and after. However, the group was not unified in its criticism of Touré: the Dresden contingent sent a counter-telegram, supporting their leader and his position on the strike, although some in the Guinean NHG claimed that those from Dresden had signed it under duress.

The story of what happened to the Guinean students, and who were the main players in the unfolding drama, is difficult to retrace. ${ }^{17}$ It certainly involved the Guinean ambassador in Prague, members of the Guinean NHG, representatives of the GDR's Ministries of Education and International Affairs, and at least one professor from Leipzig's Karl Marx University (KMU). The ambassador came to the GDR unannounced - an infraction of East German rules - and demanded that all Guineans in the GDR proceed to a mandatory meeting in Prague. This was in preparation for their repatriation to Guinea, where they would likely be 're-educated', possibly at a camp called Alpha Yaya.

The students referred to Alpha Yaya as 'Guinea's Buchenwald', and it may have been a forerunner of the infamous Camp Boiro. The use of the name 'Buchenwald' was clearly meant to goad GDR officials from the Foreign Office who heard the term, which was voiced at the only state-sanctioned NHG meeting on the topic. The students turned to memories of Germany's recent Nazi past and linked them to current atrocities in Guinea to make the case that Touré had become an abusive dictator. Images of violence dominated the

\footnotetext{
${ }^{17}$ All documents relating to the Guinean protests come from the Political Section of the Federal Foreign Archive, MfAA.
} 
meeting, as NHG members described demonstrations in Conakry and Labé being put down in a bloodbath. They described reports that 2,000 young girls had been raped in the course of the demonstration. In a later discussion with Katharina Harig, director of the KMU's Herder Institute, one of the student leaders further insisted that the Touré government was veering towards fascism, and that the Guineans in the country lived in misery.

The GDR nevertheless sided with Touré, likely convinced that upsetting him would foreclose the possibility of establishing diplomatic ties with Guinea. Consequently, the SED moved cautiously but deliberately to silence the students. The Foreign Office allowed them the one meeting, and even provided a room for it. However, it quickly dismissed the claims of the movement's leaders and their contention that the Toure government had become so corrupt that the struggle was no longer between the people and the imperialists, but rather between the people and the authoritarian postcolonial regime. Harig labelled these students 'Feuerköpfe' (hotheads), and argued that they did not understand how a socialist revolution was supposed to work, or the students' role in it. She also described the man who met with her as the son of a wealthy plantation owner, further discrediting him as a member of the reactionary bourgeoisie. When talking to Harig, he had insisted that the students were the vanguard of the revolution and had the responsibility to lead, but she countered that the role of youth was to listen to the voices of their wiser, more experienced elders. Characterizing the students as hotheads or malcontents was typical of the GDR reaction to exchange student activists, as was their categorization as bourgeois.

While the GDR tried to stifle the students, the Guinean state reacted by recalling forty-three of the protesters. The ambassador to Prague maintained that if the students went home, they would see for themselves that Guinea was stable and Touré beloved. According to the ambassador, the GDR students were duped by imperialist propaganda from France, and there were no problems in Guinea. ${ }^{18}$ Once the students had returned, the Guinean state would replace them with other students, ostensibly Touré loyalists. Such a replacement was something the students had feared and had addressed during their meetings; they believed that an international student council should select students to go abroad, not the government. ${ }^{19}$

Whether the students did return - and whether the GDR compelled them to do so - is unclear. The Guineans in Russia had refused their recall and consequently lost the stipends that Moscow had been issuing them. In the GDR, it may have been easiest for students to go to West Berlin, since, even after the Berlin Wall was built in 1961, it was fairly easy for Africans to cross. While their specific fate is unknown, what is clear is that the students used the NHG, the organization the GDR had given them, to protest about the Touré regime's actions. As Elizabeth Schmidt has pointed out, Guineans had ample experience of activism. It was ordinary Guineans who propelled their colony to be the only one to vote for independence from France in the referendum presented in 1958. The students' case makes it plain that this activism did not cease with independence; it was used

\footnotetext{
${ }^{18}$ This was untrue. The strike did occur, as did the bloody crackdown.

${ }^{19}$ But African governments were almost always the ones that made the selections, and not only in the Guinean case.
} 
against Touré, a president who would become one of Africa's most brutal dictators. The Guinean incident also shows how student protest took on different forms depending on location. In East Germany, where open, public demonstration against a supposedly friendly foreign government was difficult, student clubs became vehicles for politics.

\section{Divisions at home, divisions abroad: Nigerian students and the Biafran crisis}

Following independence in 1960, Nigerians struggled to determine who would have the most political influence in the newly formed state - the Hausa/Fulani, the Yoruba, or the Igbo. The tense political climate after decolonization culminated in 1967 with the secession of the primarily Igbo Biafra and the Nigerian civil war, which ended in 1970. During the conflict, the GDR threw its support behind Nigeria's central government, as did the rest of the Soviet bloc. Meanwhile, those students who were Igbo remained loyal to Biafra. The division between the GDR and the Igbo students - and the division among the Nigerian students themselves - led to the existence of two Nigerian NHG, one that was officially recognized, and one that was specifically Biafran and therefore illegal.

Nigerian students were the first Africans to study in the GDR. Eleven Nigerians came to study in Leipzig in 1951, under the auspices of Nigeria's main union. Since these students had been invited to study in East Germany following a 1949 British massacre of striking miners in Enugu, the heart of Igboland and later capital of Biafra, the majority of students in the GDR were ethnically Igbo. The Nigerians were also among the first to have their own national student club. An official Nigerian NHG, the Nigerian Union of Students in the German Democratic Republic, then formed around 1960, briefly became defunct, and was revived in 1962.

In the GDR, Nigerian students followed the events in Biafra closely. As tensions in Nigeria grew, the students from Biafra began to identify themselves more strongly with their home area. ${ }^{20}$ Biafran students quarrelled with non-Biafran students on campus and in meetings of the Nigerian NHG. Tensions exploded after the civil war began and Biafra declared independence in 1967. In a report from the secretary general of the Nigerian NHG to the international studies division at the KMU, the Biafrans were portrayed as thuggish, violent radicals. The putative 'ringleader' of the Biafran group is described as carrying a long knife under his jacket, which made him a menacing figure. The university official charged with monitoring the groups concurred with the assessment of the secretary general on the Biafran leader, but went further; he put all of the man's activities under a microscope. The official criticized him not only for his involvement with the Biafran cause but also for unrelated behaviour, such as his supposed lack of

\footnotetext{
${ }^{20}$ UAL, ZM 3931/IIa-IIIa, 'Aufstellung der Vorkommnisse mit dem nigerianischen Studenten M.', 8 May 1968; UAL, ZM 3931/IIa-IIIa, 'Correspondence from the Nigerian Union of Students in the German Democratic Republic to the Rector of the KMU, International Student Division', 13 February 1968; NUS/GDR, 'Appeal for mass branch meeting', from Nigerian students C., I. and J. to 'The Branch Chairman', 8 June 1968.
} 
cleanliness. ${ }^{21}$ Attempts to discredit him were similar to those used to dismiss the Guinean students who spoke out against their government, and typical of GDR tactics towards student agitators.

The Nigerians who were not Biafran and were members of the NHG used the GDR's endorsement of their political position to condemn the opposition, and to ensure that their places as the authorized representatives of Nigeria in East Germany were secure. They did so by making clear that they were anti-Biafran and that they stood with their own federal government and the GDR. They also called attention to what they described as the disruptive, radical behaviour of the Biafrans, which they claimed was in sharp contrast to their own upstanding demeanour.

Both the president and secretary general of the Nigerian Union of Students used a GDR-sanctioned 'Nigerian evening' in February 1968 to launch their harshest attacks on the Biafran students. The secretary general described the evening as an opportunity for all Nigerians in the GDR to join in polite conversation and see if they could work out a way to live peacefully together despite their political differences. On the same night, the Biafrans had congregated upstairs in the same building for their own, separate gathering. The secretary general claimed that after the Biafran meeting ended, two of its members deliberately came down to the other meeting to provoke a riot. According to him, the two men were armed, and the threat of violence was palpable. Yet the Biafran attempt to incite bloodshed failed because the other Nigerians refused to allow themselves to be drawn into conflict. After the disruption, the rest of the evening went smoothly. Later, the Nigerian Union drew on the language of unity to make the point that, while it strove to heal political and ethnic fissures, the Biafrans inflamed them.

How the endgame played out for the Nigerian students is unclear. The GDR, coordinating with the official Nigerian NHG, managed to dissolve the Biafran Club, though doubts lingered over whether unity was possible. The leaders of the NHG spoke of trying to heal rifts, and of attempting to reincorporate the Biafrans into their ranks. Whether this happened, or if the conflict made it impossible, is an open question. However, Nigeria was an American ally and from the 1970s the numbers of Nigerian students in the GDR dropped steadily, until by the end of the decade there were only about twenty in the country. With such low numbers, the issue may have been moot. The GDR does not, however, appear to have expelled the Igbo students, or had any contact with the Nigerian federal government concerning their activities. Despite Nigeria's political stance, the SED may have retained hope that better relations with Nigeria would develop, and that continuing to welcome Nigerian students regardless of ethnicity was the wisest course.

\section{Kenyan students: a mirror of their nation}

Ethnic and political tension also shaped the history of Kenyan student organizations during the 1960s. The first Kenyan students in East Germany arrived in the

\footnotetext{
${ }^{21}$ 'Aufstellung der Vorkommnisse mit dem nigerianischen Studenten M.'.
} 
late 1950s, ${ }^{22}$ and their NHG, the Kenyan Students' Association (KSA), was established in 1960. The KSA's first chair was Owilla Ouma Olwa, a Luo student of political economy, who remained in the leadership position until $1966 .{ }^{23}$ Olwa had connections to the innermost circles of Kenya's political elite, and caught the attention of the Stasi, which assigned an informant to him in 1963 after he had returned from a trip home. ${ }^{24}$ Both the informant and Gurke, an official from the Ministry of Foreign Affairs, developed highly positive opinions of Olwa and of his commitment to socialism. ${ }^{25}$ The informant described him as linksdrall, very far to the left, ${ }^{26}$ while Gurke, in a letter of January 1966, called him 'highly intelligent'. ${ }^{27}$ In 1960, Olwa's politics clashed with those of the Kenya African National Union (KANU), which had been organized that year, just as the bloody Mau Mau emergency was ending.

Troubles within the KSA did not begin until 1964, when it split and a new group, the Kenyan Student Union, emerged to challenge the original organization. By this point, KANU was also fracturing internally, as leading figures Jomo Kenyatta, the country's president, and Oginga Odinga, its vice president, were increasingly at odds with each other. They had come together at the grass roots during Kenya's struggle for independence, but once independence came in 1963, differences among KANU's leadership arose quickly. These differences were often couched in ethnic terms, since Kenyatta was Kikuyu, Odinga was Luo, and other politicians were considered representative of their individual ethnic groups (Lamb 1969). Indeed, when discussing the breakup of the KSA, Gurke referred to the ethnic identity of the students involved. He mentioned that Olwa was Luo, and that the student who had formed the KSU, Moses Kipromo, was Kipsigis, implying that ethnic loyalty was responsible for the rift. ${ }^{28}$

Yet the place of ethnicity in causing ruptures within KANU and the KSA has been overstated, or rather ethnicity's role in galvanizing disunity is more complicated and embroiled in other issues. In the early period after independence, Kenyatta was in favour of capitalism, while Odinga leaned towards socialism (Hornsby 2012: 8, 547). Odinga ultimately broke with Kenyatta over their divergent economic beliefs, with Odinga founding an opposition party, the Kenya People's Union (KPU), in 1966. Olwa well understood the significance of the economic component behind Kenya's political divides. A Stasi informant reported that Olwa told him that the creation of the KPU 'had nothing to do with tribalism; we can see that there are well-known and influential opposition forces coming from all tribes, and especially from Kenya's three largest tribes' ${ }^{29}$ There was widespread discontent with Kenyatta's economic policies not long after independence,

\footnotetext{
${ }^{22}$ The very first Kenyan student may have been Julius Ongewe, who came to the GDR in 1958 and later had a role in the East German science fiction film Silent Star. See UAL, 'Studentenkartei Ausländer, 1965-1990'; Torner (2014: 118-37).

${ }^{23}$ MfAA, C402, Vol. 2, 'Gurke, MfAA, to Riesenweber, DAfriG', 26 January 1966.

${ }^{24}$ Ministerium für Staatssicherheit (MfS), AP 4954/73, 'Olwa, Owilla Ouma, informant report', 17 September 1963.

${ }^{25}$ 'Gurke, MfAA, to Riesenweber, DAfriG'; 'Olwa, Owilla Ouma, informant report'.

26 'Olwa, Owilla Ouma, informant report'.

${ }^{27}$ 'Gurke, MfAA, to Riesenweber, DAfriG',

${ }^{28}$ Ibid.

${ }^{29}$ MfS, AP 4954/73, 'Olwa, Owilla Ouma, Vermerk über 2 weitere Gespräche mit Herrn Ouma OLWA/Kenya, Ende März und Anfang’, April 1966.
} 
as those who had been promised an increase in their standard of living during the anti-colonial struggle realized that they would receive little material benefit, while elites divided the spoils (Parsons 2007). Olwa stood firmly behind Odinga, and hoped that his KPU would provide solutions for issues such as unemployment and landlessness, problems that he believed KANU had done nothing to address. ${ }^{30}$

The GDR originally seemed to prefer Odinga as a partner over Kenyatta. In addition to views that were seemingly more aligned with socialism, Oginga had ties to and had received funding from the USSR and China (Hornsby 2012: 72, $79,105)$. Gurke described Odinga as the "[l]eader of the progressive forces in Kenya'. His son, Raila Odinga - who would go on to become prime minister of Kenya between 2008 and 2013 - even studied in the GDR, arriving in the country in 1962 and going on to complete an engineering degree at Otto von Guericke University in Magdeburg. When KANU's National Secretary of Propaganda and Education visited the GDR in 1964, he tried to dissolve the KSA in favour of the KSU. The KSA would not yield, however, and chose Raila Odinga as their new president. ${ }^{31}$

Unity among national student groups, however, was very important to the GDR's Ministry of Foreign Affairs. There was concern that most Kenyans in the GDR were rallying around the KSU, and that the KSA would isolate itself from the rest, ostensibly incurring political problems for themselves and for the GDR. Moreover, Kenya was a one-party state, and the membership of the Kenyan national group was supposed to reflect that. Gurke maintained that this was the case even as the cracks in KANU were increasingly evident; he discussed the factions developing among Kenyan students only two months before Oginga Odinga left KANU to form the KPU (Odinga 1967).

As in the Nigerian case, Kenyan students used the fragmentation of their student organization as a means of expressing displeasure with the politics going on in their own country. With Nigeria, the GDR followed Soviet policy in denouncing Biafra in the hope of extending socialist influence in the country. Kenya appeared no different. The GDR was inclined to push the students to demonstrate a superficial united front for its own political well-being. The Soviets were originally very interested in Kenya, and especially in Oginga Odinga's politics. They provided development aid in the first half of the 1960s. By the end of the decade, however, relations between Kenya and the USSR had worsened, as the Soviets grew uncertain of Odinga's position as opposition leader (Maxon and Ofcansky 2014: 319-20).

There has been little research on the GDR's diplomatic position vis-à-vis Kenya; as with other African states, Kenya did not officially recognize the GDR in the 1960s because of the Hallstein Doctrine. The Stasi's continued cultivation of Olwa suggests that East German interest in the country's politics, and in the possibility that it might lean further left, persisted throughout the 1960s. Olwa's Stasi file extends from his arrival in 1959 to 1969. Many of the conversations that informants conducted with him concerned Kenyan politics. The Stasi considered making Olwa an Inoffizieller Mitarbeiter (IM or Unofficial

\footnotetext{
${ }^{30} \mathrm{Ibid}$.

31 'Gurke, MfAA, to Riesenweber, DAfriG'.
} 
Colleague), believing that they might be able to use him to garner more information on the political situation in the country. But they also grew increasingly unsure about whether Olwa would be of use in this capacity, as it was difficult to tell whether the socialist opposition had any chance of success. In the end, the GDR was able to compel the KSA, Olwa's group, to dissolve and join the $\mathrm{KSU}$, preserving a 'united front'. As a result, Olwa drifted away from the organization. ${ }^{32}$ Although 'unity' had been achieved, it was obviously at the expense of GDR support for the more progressive student union. It also reflected a continued East German willingness to cater to the interests of the regnant power in an African country, regardless of its position in the Cold War world.

\section{The UASA: calling out racism in the GDR}

African student politics did not exist just in relation to their countries of origin. In 1965, a rivalry exploded not within a specific, national group, but in the UASA itself. Superficially, it appeared that the dispute was between the union's chapters in Leipzig and Rostock. The Rostock members accused the Leipzig branch of being 'henchmen for the SED', and referred to it as an East German 'puppet'. Dissatisfied with what they considered corrupt representation, the Rostock contingent accordingly founded their own, alternative African student union. The Leipzigers complained and had a meeting to address internal divisions with various authorities in the city, including a party from the local FDJ. ${ }^{33}$

Below the surface, however, lurked the spectre of racism. In addition to claiming the mantle of anti-imperialism, the GDR also maintained that it was an anti-racist state. Any lingering racism was either a reflection of only a handful of retrograde, uneducated citizens (Müller 2014: 86) or the result of an insidious influence coming from the West. ${ }^{34}$ Yet the UASA alleged otherwise, and described a much more pervasive racist presence - one that was growing, not declining.

While most of the NHG protests were tied to political events in specific countries, dissent in the UASA therefore stemmed from serious concern over matters in the GDR itself. Conflict between the students in Leipzig and Rostock arose when a letter was written about East German racism. The letter was directed at Ulbricht and other leaders of the SED, presumably came from Rostock, and was signed 'The Committee of African Students and Workers in the GDR'. According to officials at the Ministry of Education, the actual writer was probably a Togolese philosophy student. The letter opened with a statement that tensions

\footnotetext{
${ }^{32}$ MfS, AP 4954/73, 'Olwa, Owilla Ouma, "Einschätzung der KP 'Olga' und ihrer erfolgten Aufklärung”, Keller, Berlin', 18 November 1968.

${ }^{33}$ MfAA B1263/75 Abt. Afrika, Sektion Gesamtafrikanische Fragen, Aufteilung des Studentenkontingents f. Afrikanischen Staaten, 1972-73, 'Information über die in Zusammenhang mit dem Brief der Union afrikanischer Studenten in der DDR festgelegten Maßnahmen vom 12. März 1965'.

${ }^{34}$ SAPMO, DY/24/8752, 'Zentralrat der FDJ, Zentralarchiv, Bestand: Intern. Verbindungen, 1961-1965. Einschätzung der Aussprachen mit den Delegationen des II. Internationalen Halbjahreslehrganges - Afrika - 1962', 14 August 1962. This report suggests that Western influence on East Germany was one of the primary reasons for the existence of any lingering racism in the country.
} 
between African students and workers and East German citizens were on the rise. There was an upsurge in provocations on both sides, and these were increasingly resulting in physical hostilities. The writer warned that if something was not done soon, there would be a major confrontation that could lead to negative reports filtering out to the anti-communist, Western press. The GDR typically suppressed any news suggestive of racism inside the state (Frindte 1990: 88-96), but the student implied that stories about recent racist incidents were bound to get out. He believed, then, that it was in the best interests of the GDR to negotiate with the UASA and work on reducing such incidents. ${ }^{35}$

Like the Guinean students who had referenced Germany's Nazi past in their protests, the author of the letter did not shy away from discussions of the Third Reich and the continuing Nazi influence in the GDR. He said that a minority of African students, especially the older ones, were not conversant with postwar German history. Consequently, they failed to recognize that there were 'certain subversive elements in the GDR still associated with (the notorious) Hitlerism', and were more likely to be surprised, or provoked, by encounters with regressive elements. Moreover, these Africans did not realize that the GDR was now committed to socialism, an inherently anti-fascist ideology, and perhaps saw isolated incidents of racism as reflective of wider state policy. These students were anti-socialist, probably because they saw socialism as akin to racism.

While he did not mention the work of francophone scholars such as Cheikh Anta Diop, Frantz Fanon and Aimé Césaire explicitly, the letter writer continued his argument about African sensitivity to racism in language reminiscent of theirs. Diop, Fanon and Césaire wrote copiously, and in the mid-1960s their work would have been widely available, if not necessarily to East Germans then certainly to Africans who had more geographical mobility. French-speaking Africans such as the Togolese author of the UASA letter would probably have been even more conversant with these intellectuals, given the francophone link. ${ }^{36}$

The letter writer's suggestion that colonialism had such a negative impact on Africans that they were now wary of any whites, including those with good intentions, was especially evocative for the francophone intellectuals. For his part, Diop contended that Europeans had convinced Africans of their inferiority, and that this had caused generations of irreparable psychological harm (Diop 1999 [1955]). Fanon similarly argued that whites had ingrained the idea that blacks were evil or depraved so deeply that the only way for blacks to survive was to put on 'white masks' that hid the shame of their blackness (Fanon 2008 [1952]). Césaire famously discussed how colonialism had destroyed African cultures (Césaire 2010). Césaire also broke with the French communist party over the persistence of racism in countries that now claimed to be socialist, European socialists' fundamental misunderstanding of the complex differences between the

\footnotetext{
${ }^{35}$ MfAA B1263/75 Abt. Afrika, Sektion Gesamtafrikanische Fragen, Aufteilung des Studentenkontingents f. Afrikanischen Staaten, 1972-73, 'Besorgnisse der afrikanischen Studenten und Arbeiter in der DDR', February 1965.

${ }^{36}$ In addition, there was already strong support for Pan-Africanism among the African student population in the GDR. Diop, Fanon and Césaire embraced Pan-Africanist principles, as well as those of its French cousin Négritude, which Césaire had co-founded.
} 
struggle of European workers against capitalism and that of blacks against colonialism, and their refusal to admit the atrocities and prejudices of Stalin (ibid.).

Following the francophone intellectuals, the writer stated that East Germans understood neither the depth of black psychological angst nor how simply 'poking fun' at Africans could awaken deep-seated anger against whites. There were some who were blatantly racist and had never broken with the Nazi past or accepted the anti-racist, anti-imperialist message of the GDR. Of these, the most devious were those who pretended to be anti-racist, only later to reveal their true nature. Their sordid intentions were additionally bound up in the broader struggle between capitalism and communism, insofar as they made the Africans doubt the solidity of socialism in the GDR and the morals of the SED. These individuals baited Africans in the hope that the news of racism in the GDR would get out and damage its image in the West. Cold War politics were, in effect, the motor behind much of the racism members of the UASA had encountered, and the African reaction was natural given the hardships experienced under colonialism. ${ }^{37}$

Racist behaviour was not limited to teasing. The writer held that groups of East German men had recently come together to beat up Africans; two students had been assaulted the week before and almost died from their injuries. The African community was understandably outraged. What was to be done? The author had some suggestions. He recommended having experienced students give lectures on German life and customs to new arrivals while they were at the Herder Institute, the language-learning centre all exchange students attended before continuing to university; setting up a recreation room for African students, where they could contact the eight-member UASA council about any concerns they might have; sponsoring lectures on postcolonial Africa in factories and other venues; compelling the Deutsche Film Aktien-Gesellschaft (German Film Corporation or DEFA) to produce movies on contemporary Africa, since most of what they were currently making reflected only 'colonial barbarism'; and, finally, holding meetings with African students to address the serious problems that everyone faced. The proposal that universities provide space for an African recreation room came with a subtle dig at the East German state, since the writer claimed a similar step had been taken in the FRG, with notable success. ${ }^{38}$

Both the Ministry of Foreign Affairs and the Ministry of Education took the letter very seriously. In private conversations officials described the situation as one of Dringlichkeit (urgency), and in general agreed with the letter's conclusion that violent clashes between East Germans and Africans were on the rise. ${ }^{39}$ A Dr Fischer who worked in the Department of Education talked with colleagues and explained that, after discussion with local police and security, he believed that the opinions expressed in the letter accurately reflected those of the wider African

\footnotetext{
${ }^{37}$ 'Besorgnisse der afrikanischen Studenten und Arbeiter in der DDR'.

${ }^{38}$ Ibid.

${ }^{39}$ MfAA B1263/75 Abt. Afrika, Sektion Gesamtafrikanische Fragen, Aufteilung des Studentenkontingents f. Afrikanischen Staaten, 1965, 'Aktenvermerk über ein Gespräch mit Dr. Joachimi, Staatssekretariat für das Hoch und Fachschulwesen, am 2. März 1965, 10:00 bis 11:20', 3 March 1965.
} 
community. ${ }^{40}$ Certain concrete measures to combat racism among East Germans were also put in place. For example, a group from the Ministry of Education tasked the Rostock authorities with speaking to the head of the taxi drivers' union, whose drivers frequently directed slurs at Africans, and have him correct their behaviour. ${ }^{41}$ More generally, the ministry should send working groups (Brigaden) to different unions and have them address the importance of solidarity with the developing world. These groups would 'above all explain that international solidarity in the GDR is not limited to donations, but forged through the relationship to Africans in the GDR itself'. ${ }^{42}$ Along with increased communal engagement on the part of DAfriG and the FDJ, these steps would form the basis of anti-racist education for the public.

Since the GDR tended to brush off accusations of racism, or to see them as exclusively due to Western interference, it is significant that it considered taking these steps to address racism inside the country. This anxiety over the increase in racism, however, was probably grounded in the possibility that stories about confrontation would be leaked to the Western press and undermine the narrative of socialist solidarity that the GDR wanted to project. Because much of the discussion took place before a congress of African students that was to be held in the GDR later that spring, officials worried that 'right-wing' elements in the UASA might seize the initiative to speak out about their problems in the GDR, damaging the state. ${ }^{43}$ Further, despite officials' concerns about the behaviour of GDR citizens, African students and workers were not considered free from blame. They submitted that it was the UASA's responsibility to monitor the behaviour of African students, as well as to teach them about the finer points of the conflict between the GDR and its political opponents. Tired accusations that Africans were likely drinking too much and visiting ignominious bars were dredged up, and GDR administrators told the UASA that it should ensure that its members knew about the dangers of alcohol. The UASA was also to educate those students who had a more 'delicate' sensibility about adapting to the GDR and, ostensibly, its racism. ${ }^{44}$ In other words, those students who had developed a negative opinion of whites over the course of many years under colonialism needed to toughen up and ignore whatever racism they encountered in the GDR.

In the end, the GDR's response to an African protest directed against itself rather than towards the policies of an African state was ambivalent. There was recognition of racism inside its borders, as well as fear about what this racism might mean for the country's international profile. At the same time, the GDR fell back on its more familiar narrative of African responsibility for East

\footnotetext{
${ }^{40}$ MfAA B1263/75 Abt. Afrika, Afrika, Sektion Gesamtafrikanische Fragen, Aufteilung des Studentenkontingents f. Afrikanischen Staaten, 1965, 'Auszug aus einem Aktenvermerk über eine am 11.3.65 stattgefundene Beratung des Staatssekretariats für das Hoch- und Fachschulwesen mit Vertretern zentraler Dienststellen, die für die Ausbildung und Betreuung von Auslandsstudenten zuständig sind'.

41 'Information über die in Zusammenhang mit dem Brief der Union afrikanischer Studenten in der DDR festgelegten Maßnahmen vom 12. März 1965'.

${ }^{42}$ Auszug aus einem Aktenvermerk über eine am 11.3.65 stattgefundene Beratung des Staatssekretariats für das Hoch- und Fachschulwesen mit Vertretern zentraler Dienststellen'.

${ }^{43}$ 'Information über die in Zusammenhang mit dem Brief der Union afrikanischer Studenten in der DDR festgelegten Maßnahmen vom 12. März 1965'.

${ }^{44}$ Ibid.
} 
German racism, one based on beliefs in African backwardness, weakness in the face of temptation, and overt sensitivity.

\section{Conclusion}

This article has drawn attention to the ways in which African students were able to use their NHG and the UASA as vehicles for political protest in a state that tried, often unsuccessfully, to circumscribe political action not reflective of SED-sanctioned policies or narratives. The students challenged not only East German leadership and its attempts to shape their opinions in various venues, but also the very governments that had sent them to the GDR in the first place. In the introduction to this special issue, Dan Hodgkinson and Luke Melchiorre (2019) argue that, in this era, African students generally recognized that university education lent them power to harness nationalist and other political discourses in the same way that their leaders did. This was something that the students in East Germany certainly understood, as they confronted hierarchies of authority at home and abroad.

Student power extended, for instance, to the exposure of hypocrisy. The GDR's cautious approach to Guinea's Touré, whom passionately Marxist students declared was a fascist, undercut its own commitment to both Marxist ideology and anti-imperialism. Siding with the dictator in a purely pragmatic move, the SED demonstrated that it was willing to jettison the core principles of the East German state in favour of shoring up already shaky ties with Guinea. Here, the students were able to accentuate the multiple registers in which supposed 'allies' operated, and how Marxism-Leninism was unable to become the unifying tool that the GDR believed it would be. Armed with both a complex understanding of Marxism-Leninism and the brutality of recent German history, they brought the viciousness of the Toure regime into the spotlight, and revealed the political moral inconsistencies of East German leadership at the same time.

In the 1970s, other African student groups became politically active; as mentioned briefly above, Malians protested against changes in their government in $1971,{ }^{45}$ and the student associations of both Somalia and South Africa expressed dissent later in the decade. ${ }^{46}$ Such protests demonstrated a continuing engagement with domestic politics in their individual countries, and a concomitant resistance to that engagement on the part of the GDR. For example, anxieties surrounded plans by the group from the Republic of Congo to hold a seminar on current events for students from that country in late March 1977. The Office for Study Abroad at the KMU in Leipzig expressed concern about a lecture on the "politics of the USSR and other socialist countries as regards détente and militarization, as well as their attitude toward solidarity with free, independent, and still oppressed

\footnotetext{
${ }^{45}$ 'Beziehungen zwischen der DDR und Mali auf dem Gebiet des Hoch- und Fachschulwesens, 1967-71'.

${ }^{46}$ UAL, ZM 3962, 'Discourse prononcé par S. E. Eyemi Richard, Ambassadeur du Congo à l'occasion de la fête de la Jeunesse Congolais à Leipzig', 8 February 1977.
} 
nations' ${ }^{47}$ The concern was that remarks might be made about the political situation in Congo-Brazzaville, and such remarks were forbidden. ${ }^{48}$ In February, the Congolese ambassador to the GDR had made a speech at the Festival of Congolese Youth in Leipzig, in which he praised his country's stance against the forces of imperialism. However, on 18 March, the country's president, Marien Ngouabi, was assassinated. Ngouabi was a socialist and had proclaimed CongoBrazzaville Africa's first Marxist-Leninist state when he took power in 1968. The quick changes roiling Congo-Brazzaville made the SED cautious about supporting the students, even though they were Marxists, and thus supposedly Cold War allies.

African students in the GDR were highly politicized and vocally critical of actions they rejected in their home countries. The GDR was loath to let news of student activism spread beyond its borders, and apprehensive about upsetting relations with emergent African states. Indeed, the politics of the state in question - socialist or not - mattered less than the possibility that fragile diplomatic bonds might be broken. This undermined the GDR's narrative of itself as an ardent supporter of those still struggling for independence, or working to build new nation states. Indeed, it is possible to imagine that the GDR feared alienating groups such as the ANC, with whom it maintained close ties and that it supported in a variety of ways (Thomas 1995). When Africans questioned GDR policy in their own states, or challenged its anti-racist narrative by pointing out the persistence of racism in East Germany, they demonstrated that their position brought with it the authority to challenge and reprimand their benefactors.

\section{References}

Césaire, A. (2010) 'Culture and colonization', Social Text 28 (2/103): 127-44. Diop, C. A. (1999 [1955]) Nations Négres et Culture. Paris: Présence Africaine. Fanon, F. (2008 [1952]) Black Skin, White Masks. New York NY: Grove Press. Frindte, W. (1990) 'Sozialpolitische Anmerkungen zur Entwicklung Rechstradikaler Tendenzen in der DDR' in H. Butterwegge and C. Isola (eds), Rechstextremismus im Vereinten Deutschland. Bremen: Steintor.

Hodgkinson, D. and L. Melchiorre (2019) 'Introduction: student activism in an era of decolonization', Africa 89 (S1): S1-S14.

Hornsby, C. (2012) Kenya: a history since independence. London: I. B. Tauris.

Lamb, G. B. (1969) 'The political crisis in Kenya', World Today 25 (12): 537-44.

Maxon, R. M. and T. P. Ofcansky (2014) Historical Dictionary of Kenya. Lanham MD: Rowman and Littlefield.

Müller, T. R. (2014) Legacies of Socialist Solidarity: East Germany in Mozambique. Lanham MD: Lexington Books.

Odinga, O. (1967) Not Yet Uhuru. London: Heinemann.

Parsons, T. (2007) 'The Lanet incident, 2-25 January 1964: military unrest and national amnesia in Kenya', International Journal of African Historical Studies 40 (1): 51-70.

\footnotetext{
${ }^{47}$ UAL, ZM 3962, 'Letter from Dr M. Schmidt to Professor Voight, Direktor der Sektion Afrika- und Nahostwissenschaften, KMU', 11 March 1977.

${ }^{48}$ UAL, ZM 3962, 'Aktennotiz', 30 March 1977.
} 
Schenck, M. C. (2019) 'Negotiating the German Democratic Republic: Angolan student migration during the Cold War, 1976-90', Africa 89 (S1): S144-S166.

Slobodian, Q. (2012) Foreign Front: Third World politics in sixties West Germany. Durham NC: Duke University Press.

Slobodian, Q. (2013) 'Bandung in divided Germany: managing non-aligned politics in East and West, 1955-1963', Journal of Imperial and Commonwealth History 41 (4): 644-62.

Tatum, D. (2002) Who Influenced Whom? Lessons from the Cold War. Lanham MD: University Press of America.

Thomas, S. M. (1995) The Diplomacy of Liberation: the foreign relations of the ANC since 1960. London: I. B. Tauris.

Torner, E. (2014) 'Casting for a socialist earth: multicultural whiteness in the East German/Polish science fiction film Silent Star' in S. Fritzche (ed.), The Liverpool Companion to World Science Fiction Film. Liverpool: Liverpool University Press.

Winrow, G. (1990) The Foreign Policy of the GDR in Africa. Cambridge: Cambridge University Press.

\begin{abstract}
African students in the German Democratic Republic (GDR) often belonged to national student clubs (NHG) that were arranged for them by the East German government. Many were also members of an umbrella organization for all African students and workers in the GDR (UASA). While the GDR authorities thought that the NHG and UASA would adopt political positions that reflected those of the GDR, this article demonstrates that the students instead used them to criticize both their own governments and their host country. It shows that the students often held positions contrary to the GDR's, and were not shy about expressing them. Although they were usually unable to organize as openly as students in the West, African students in the GDR held meetings and wrote letters to protest about a variety of issues, including Sékou Touré's repression of a teachers' strike in Guinea, the Biafran crisis in Nigeria and ethnic separatism in Kenya. They also took the GDR to task for the racist behaviour of East German citizens. The GDR's Socialist Unity Party claimed that the country was anti-racist and anti-imperialist, and that all vestiges of Nazism had been expunged; the students, however, were able to point out multiple racist incidents, and through the UASA demanded that the GDR address its racism problem.
\end{abstract}

\title{
Résumé
}

En République démocratique allemande (RDA), les étudiants africains étaient souvent membres de clubs étudiants nationaux (NHG) mis à leur disposition par le gouvernement est-allemand. Beaucoup étaient également affiliés à une organisation parapluie regroupant les étudiants et travailleurs africains en RDA (UASA). Alors que les autorités est-allemandes pensaient que les NHG et l'UASA adopteraient des positions politiques qui reflèteraient celles de la RDA, cet article démontre que les étudiants ont au contraire utilisé ces groupes pour critiquer leurs propres gouvernements et leur pays d'accueil. Il montre que les étudiants avaient souvent des positions contraires à celles de la RDA et ne craignaient pas de les exprimer. Ils ne pouvaient pas s'organiser aussi ouvertement 
que les étudiants de RFA, mais les étudiants africains en RDA tenaient des réunions et écrivaient des lettres de protestation sur différents sujets comme la répression d'une grève d'enseignants par Sékou Touré en Guinée, la crise du Biafra au Nigeria ou le séparatisme ethnique au Kenya. Ils ont également pris la RDA à partie pour le comportement raciste des citoyens est-allemands. Le Parti socialiste unifié de la RDA affirmait que le pays était antiraciste et antiimpérialiste, et que tous les vestiges du nazisme avaient été effacés ; les étudiants ont cependant pu relever de multiples incidents racistes et, par le biais de l'UASA, exiger que la RDA s'attaque à son problème de racisme. 